\title{
DETERMINATION OF TRANS-10-HYDROXY-2-DECENOIC ACID (10-HDA) IN ROYAL JELLY FROM SÃO PAULO STATE, BRAZIL ${ }^{1}$
}

\author{
Luis Henrique GARCIA-AMOEDO ${ }^{2}$, Ligia Bicudo de ALMEIDA-MURADIAN ${ }^{2, *}$
}

\section{SUMMARY}

The 10-HDA content in Brazilian samples (São Paulo State) of royal jelly (RJ) was analyzed using an HPLC method based on the work by BLOODWORTH et al. [2]. The chromatographic conditions were: isocratic system, reversed phase $\mathrm{C}_{18}-\mathrm{H}$ column, auto sampler, diode array UV-VIS detector adjusted to $225 \mathrm{~nm}$, mobile phase composed by methanol/water (45:55) at $\mathrm{pH}=2.5$ adjusted with phosphoric acid; $\alpha$-naphtol was used as internal standard, and the running time was $30 \mathrm{~min}$. By statistical analysis of the results, the 10-HDA contents of the samples analyzed seem to have two ranges: $1.8 \%$ and $3 \%(\mathrm{w} / \mathrm{w})$, that would be useful to qualify the RJ. This is the first data regarding 10-HDA content of Brazilian RJ.

Keywords: trans-10-hydroxy-2-decenoic acid; 10-HDA; royal jelly; beehive product; HPLC analysis

\section{RESUMO}

DETERMINAÇÃO DO ÁCIDO 10-HIDROXI-TRANS-2-DECENÓICO (10-HDA) NA GELÉIA REAL DE SÃO PAULO, BRASIL. Foi analisado o conteúdo de 10-HDA em amostras de geléia real (GR) do Estado de São Paulo, Brasil, utilizando-se o método de cromatografia líquida de alta eficiência baseado no trabalho de BLOODWORTH et al. [2]. As condições cromatográficas foram: sistema isocrático, coluna $\mathrm{C}_{18}-\mathrm{H}$ de fase-reversa, injetor automático, detector de arranjos de foto-diodo ajustado a $225 \mathrm{~nm}$, fase móvel composta de metanol/água (45:55) com $\mathrm{pH}=2,5$ ajustado com ácido fosfórico, $\alpha$-naftol como padrão interno e tempo de corrida de 30min. Pela análise estatística dos resultados, os teores de 10-HDA das amostras analisadas apresentaram duas faixas principais: de 1,8\% e de $3 \%$ (p/p), o que seria útil para classificar a GR. Este é o primeiro trabalho que contém dados sobre o teor de 10-HDA em amostras de GR brasileira.

Palavras-chave: ácido 10-hidroxi-trans-2-decenóico; 10-HDA; geléia real; produtos da colméia; cromatografia líquida de alta eficiência.

\section{1 - INTRODUCTION}

Royal jelly $(\mathrm{RJ})$ is a viscous substance secretioned by the mandibular hypofaringeal glands of the young worker bees and serves as food for the developing larves and for the queen bee during its entire life. $R J$ is composed by aminoacids, carbohydrates, lipids, vitamins, minerals and a characteristic compound, that is always present: trans-10-hydroxy- 2-decenoic acid (10-HDA), whose description was made by BARKER et al. [1].

Since that time, studies from the literature have been quoting the antimicrobiane activity of $\mathrm{RJ}$ and this activity is sometimes an attribute of 10-HDA. In 1959, TOWNSEND, MORGAN \& HAZLET [13] described the activity of 10-HDA against experimental leukemia and ascitic tumors. The antibiotic activity of 10-HDA was the aim of the study of BLUM, NOUAK \& TABER [3]; in 1959 , the authors quoted that 10-HDA is the major component of the lipidic fraction of RJ and it presents antibiotic and antimicrobiane activity against bacteria and mold. The authors noticed that the salt of this compound was less active compared with the free acid.

Studying the lipidic fraction of RJ, WEAVER et al. [14], three compounds were separated and identified from pure RJ: the 8-hydroxy-octanoic, 3-hydroxy-decanoic and 3,10-dihydroxy-decanoic acids. The last one is probably an important precursor of the 10-HDA.

1. Recebido para publicação em 01/11/2001. Aceito para publicação em 07/07/2003 (000770).

${ }^{2}$ Faculdade de Ciências Farmacêticas da Universidade de São Paulo. Departamento de Alimentos e Nutrição Experimental. Av. Prof. Lineu Prestes 580,Bloco 14,CEP 05508-900,São Paulo, SP. ligiabi@usp.br.

* A quem a correspondência deve ser enviada.
LERCKER et al. [9] published a study about the lipidic fraction of RJ. The authors used thin layer chromatography and gas chromatography with mass spectrum. They identified a series of fatty acids of short chain, and some of them were dicarboxilics including 10-HDA. In 1982, the same authors [10] separated hydrocarbons and steroids from the lipidic fraction of RJ.

In 1992, PALMA [12], based in the fact that in Brazil there is no standards to make the quality control of $R J$ to be used by the regulatory agencies of the government, started a study to determine the chemical composition of Brazilian RJ. He analyzed moisture, protein, ash, lipid, sugar content and acidity. The author verified that the composition was almost the same as the composition found by other authors from literature and the main difference is that Brazilian samples had higher values of moisture compared with other values cited in literature.

Knowing the fact that 10-HDA is the active substance of $\mathrm{RJ}$ and recognizing its importance concerning the determination of the quality of the product, BLOODWORTH et al. [2] proposed a method for its determination using high performance liquid chromatography (HPLC), comparing the HPLC advantages against gas chromatography. As $R J$ is the unique natural product that has 10-HDA, this acid can be used as an indicator of its authenticity for pure RJ as well as for the products that contain RJ. GENÇ \& ASLAN [7] also used HPLC method to measure the 10-HDA concentrations in Turkish and Chinese RJ.

JIA, ZHANG \& HU [8] proposed a method of analysis of 10-HDA with capillary electrophoresis.

The objective of the present work is to determine 10HDA, using the HPLC method based in the 
BLOODWORTH et al. [2] in samples of Brazilian RJ, since there is no data published about 10-HDA content using Brazilian samples of royal jelly.

It must be quoted that the analytical data presented herein were based in the MS Dissertation of GARCIA-AMOEDO [6] which was cited as a reference method for the determination of 10-HDA in the Brazilian regulation of RJ [4] from Agriculture Ministry. This regulation demands a minimum of $2 \%(\mathrm{w} / \mathrm{w})$ in dry basis for royal jelly.

\section{2 - MATERIAL AND METHOD}

\section{1 - Material (RJ)}

\section{- Raw material selection}

Seven samples of RJ (300g) were selected from beekeepers of São Paulo State, Brazil, in 1998. These samples represent the totality of the commercial producers of RJ in São Paulo State.

All samples were kept frozen at $-18^{\circ} \mathrm{C}$ and protected from light, from the receiving time to the analysis procedure. Each sample corresponds to a different beekeeper and a different batch of production (labeled with letters A, B, C, D, E, F and G).

\section{- 10-HDA Standard}

The reference standard of trans-10-hydroxy-2decenoic acid was acquired from Nippon Shoji Kaisha Ltd. - Chuo-Ku, Osaka, Japan.

\section{- Sample preparation}

Thirty mg of RJ were weighed in a volumetric flask of $10 \mathrm{~mL} ; 1 \mathrm{~mL}$ of $\alpha$-naphtol solution was added (with concentration of $30 \mu \mathrm{g} / \mathrm{mL}$ ), and the volume was completed with mobile phase. The solution was filtered through a $0.22 \mu \mathrm{m}$ membrane, and $5 \mu \mathrm{L}$ were injected in the chromatographic system.

\section{2 - Methods}

\subsection{1 - HPLC determination of trans-10- hydroxy- 2-decenoic acid (10-HDA)}

The 10-HDA determination was similar to that used by BLOODWORTH et al. [2], changing the primarily $\mathrm{C}_{18}$ column for a $\mathrm{C}_{18}-\mathrm{H}$. The High Performance Liquid Chromatography (HPLC) technique was used under the following conditions: an isocratic system with a Shimadzu ${ }^{\circledR}$ LC9A pump, an auto sampler and a diode array UV-VIS detector (Shimadzu ${ }^{\circledR}$ SPD-MXA). The column used was a reversed phase column $\mathrm{C}_{18}-\mathrm{H}$ (Shimadzu® ODS-H with dimensions of $4.0 \times 150 \mathrm{~mm}$ cod. 228-21336-01). The mobile phase was composed of methanol/water (45:55); the $\mathrm{pH}$ was adjusted to 2.5 with phosphoric acid, filtered through $0.45 \mu \mathrm{m}$ membrane (Millipore ${ }^{\circledR}$ ) and degassed during $5 \mathrm{~min}$ with helium gas. The flow rate was $0.5 \mathrm{~mL} / \mathrm{min}$. The detector was adjusted to $225 \mathrm{~nm}$. The running time for analysis was $30 \mathrm{~min}$. The internal standard used was $\alpha$-naphtol. Data were obtained using the software SPD-MXA (Shimadzu®).

A standard curve was constructed with five points of concentrations $(\mu \mathrm{g} / \mathrm{mL})$ : $2.73,5.46,10.92,16.38$ and 21.84 of 10 -HDA, adding $\alpha$-naphtol as an internal standard, to obtain a final concentration of $3.0 \mu \mathrm{g} / \mathrm{mL}$ in mobile phase, filtered through $0.22 \mu \mathrm{m}$ membrane (Millipore ${ }^{\circledR}$ ), and finally $5 \mu \mathrm{L}$ were injected in the chromatographic system.

\subsection{2 - Evaluation of method accuracy and precision}

The evaluation of method accuracy was made by a recovery test using a known amount of 10-HDA spiked into sample matrix. The spiked samples were prepared at two levels: adding 50\% (1 mg of 10HDA primary standard) and $150 \%$ (3.5mg 10HDA primary standard) of the initial sample concentration (2mg of 10-HDA).

The precision was evaluated by the relative standard deviation (RSD) value.

\subsection{3 - Evaluation of the minimal detectable quantity}

The determination of the Detection Limit (LOD) was based on the procedures described by DADGAR \& KELLY [5] and MORENO \& SALVADÓ [11], as the 10-HDA quantity that produced a response detectable three times above noise level of the baseline.

\subsection{4 - Identity confirmation}

The confirmation of the identity of the compound was made by spectrum overlay. It was used the software SPDMXA Shimadzu® (a tool of diode array UV-VIS detector).

\subsection{5 - Statistical analysis}

The statistical analysis was made using variance analysis, contrast method and Duncan test.

\section{3 - RESULTS AND DISCUSSION}

\section{1 - 10-HDA determination in royal jelly samples from São Paulo State, Brazil}

Figure 1 shows typical chromatogram of 10-HDA from pure RJ. The retention time of 10-HDA was $14.32 \mathrm{~min}$.

Table 1 shows the levels of the trans-10-hydroxy-2decenoic acid (10-HDA) found in pure RJ. Concentration of 10-HDA in pure RJ ranged from 1.58 to $3.39 \%$.

A statistical analysis was used for the results of Table 1 regarding the means of the percentage of 10 HDA in each sample. Using the variance test, at the level of $5 \%$, the means were different from each other. Using the contrast method it was possible to verify which samples were statistically equivalent (Figure 2). 
TABLE 1. Trans-10-hydroxy-2-decenoic acid (10-HDA) determination in Brazilian royal jelly $(\%-w / w)$

\begin{tabular}{ccc}
\hline Samples & $\begin{array}{c}\text { 10-HDA } \\
(\text { mean })\end{array}$ & $\begin{array}{c}\text { Standard } \\
\text { deviation }\end{array}$ \\
A & 1.58 & 0.10 \\
\hline B & 3.17 & 0.23 \\
C & 3.39 & 0.37 \\
D & 2.70 & 0.30 \\
E & 1.98 & 0.12 \\
F & 3.10 & 0.14 \\
G & 1.82 & 0.28 \\
Mean & 2.53 & 0.73 \\
\hline
\end{tabular}

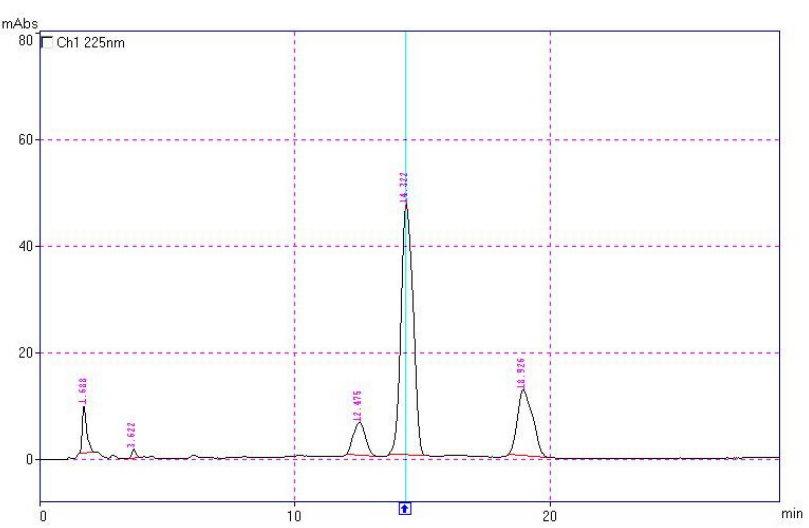

Analysis conditions: column C18-H (Shimadzu $®$ ), mobile phase: methanol / water $(45: 55), \mathrm{pH}=2.5$, flow rate $=0.5 \mathrm{~mL} / \mathrm{min}$, detector UV-VIS $(225 \mathrm{~nm})$, internal standard $=\alpha$-naftol

FIGURE 1. Typical chromatogram of 10-HDA from pure royal jelly

From the Duncan test it can be observed that the obtained values of 10-HDA were basically in two levels: the samples $\mathrm{C}, \mathrm{B}$ and $\mathrm{F}$ were equivalent ( $3 \%$ level) and the samples $\mathrm{E}, \mathrm{G}$ and $\mathrm{A}$ were equivalent (1.8\% level). BLOODWORTH et al.[2] related contents of 10-HDA of $2.80,6.37$ and $4.21 \%$ in Chinese samples, $2.79 \%$ in Australian samples and $1.98 \%$ in samples of unknown origin. GENÇ \& ASLAN [7] obtained a range from $0.33 \%$ to $2.54 \%$ of $10-\mathrm{HDA}$ in Chinese and Turkish pure RJ, and from $0.009 \%$ to $0.054 \%$ in RJ products.

\section{2 - Method accuracy and precision}

The recovery determined by the standard addition method was found to be $99.26 \pm 1.93 \%$ (mean \pm standard deviation) when was added $50 \%$ of the initial concentration and $99.81 \pm 1.61 \%$ when was added $150 \%$ of the initial concentration.

The relative standard deviation (RSD) obtained (12 replicates) for the two concentration levels from recovery test was 1.94 when was added $50 \%$ of the initial concentration and 1.61 when was added $150 \%$ of the initial concentration. These values showed the correlation among the replicates indicating the precision of the method.

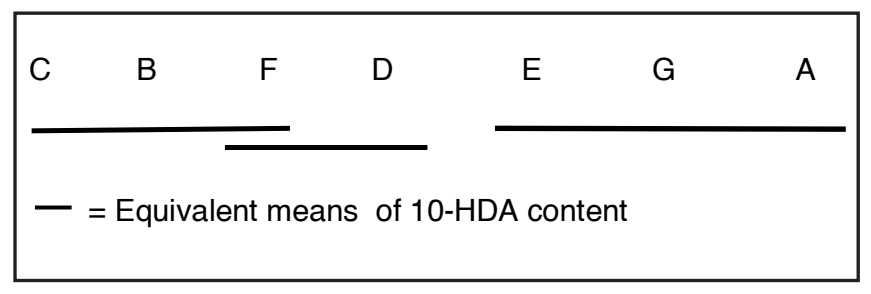

FIGURE 2. Results of the contrast analysis (Duncan method) of 10-HDA contents of Brazilian royal jelly.

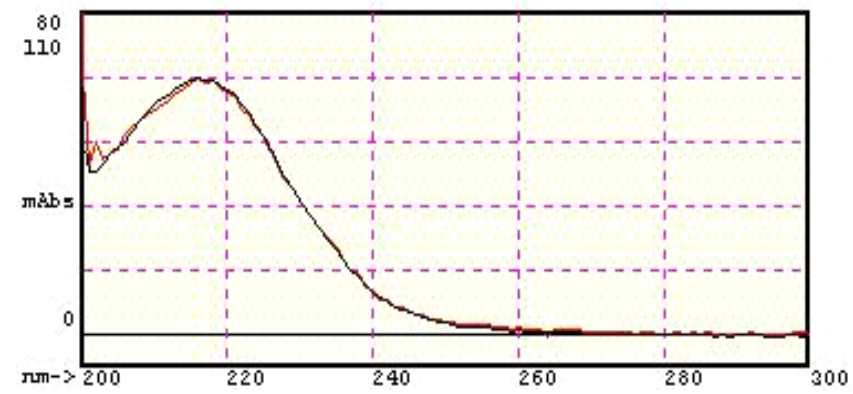

FIGURE 3. Absorption spectrum overlay between the 10HDA standard and the samples of RJ.

\section{3 - Minimal detectable quantity}

The detection limit (LOD) obtained was 21 ng of 10-HDA.

\section{4 - Identity confirmation}

Figure 3 presents the spectrum overlay of 10-HDA from reference standard and from samples, indicating a very good correlation (99.97\%) between the samples and the standard.

\section{4 - CONCLUSIONS}

According to the obtained results, it can be concluded :

- The method used, adapted from BLOODWORTH et al. [2] procedure, was good enough for the quantification of 10-HDA in Brazilian samples of $\mathrm{RJ}$, with a recovery of $99.81 \%$ and a detection limit of $21 \mathrm{ng}$, that is considered a satisfactory limit as the samples appear in mg level.

- It was possible to verify the purity of the samples by the overlay of the 10-HDA spectrum with a correlation of $99.97 \%$.

- The 10-HDA content, in Brazilian RJ seems to have two ranges: at $1.8 \%$ and $3 \%$, what would be useful to qualify the type of RJ.

- The 10-HDA content in Brazilian RJ was in complete accordance with the "Instrução Normativa n. 3 de 2001 " which demands the minimum of $2 \%$ dary weight for RJ. 


\section{5 - REFERENCES}

[1] BARKER, S.A., FOSTER, A.B., LAMB, D.C., HODGSON, N. Identification of 10-hydroxy-D2-decenoic acid in Royal Jelly. Nature, v.183, n.4666, p. 996-997, 1959.

[2] BLOODWORTH, BC., HARN, C.S., HOCK, C.T., BOON, Y.O. Liquid chromatographic determination of trans10-hydroxy-2-decenoic acid content of commercial products containing Royal Jelly. J. AOAC Int., v.78, n.4, p. 1019-1023, 1995.

[3] BLUM, M.S., NOVAK, A.F., TABER, S. 10-hydroxy-D2decenoic acid, an antibiotic found in Royal Jelly. Science, v.130, p.452-453. 1959.

[4] BRASIL, Instrução Normativa n.3 de 19 de janeiro de 2001. Regulamentos Técnicos de Identidade e Qualidade de apitoxina, cera de abelha, geléia real, geléia real liofilizada, pólen apícola, própolis e extrato de própolis. [online]: http://www.agricultura.gov.br/sda/dipoa/ instrução_normativa03_01.htm

[5] DADGAR, D., KELLY, M. High-performance liquid chromatrographic determination of xipamide in human plasma. Analyst, v. 113, p. 229-231, 1988.

[6] GARCIA-AMOEDO,L.H. Análises físico-químicas e químicas úteis para a caracterização e detecção da autenticidade ou adulteração do produto. São Paulo, 1999. 69 p. Dissertação de Mestrado (Mestre em Ciência dos Alimentos) - Faculdade de Ciências Farmacêuticas, Universidade de São Paulo (USP).

[7] GENÇ, M, ASLAN, A. Determination of trans-10-hydroxy2-decenoic acid content in pure Royal Jelly and Royal Jelly products by column liquid chromatography. J. Chromatogr. A, v. 839, p. 265-268, 1999.
[8] JIA, L.; ZHANG, H.X.; HU, Z.D. Separation and determination of 10-hydroxy-2-decenoic acid in Royal Jelly by capillary electrophoresis. Chromatographia, v. 41, n. 9/10, p. 605-609, 1995.

[9] LERCKer, G.; CAPELlA, P.; CONTE, L.S.; RUINI, F. Components of Royal Jelly. I. Identification of the organic acids. Lipids, v. 16, n. 12, p. 912-919, 1981.

[10] LERCKER, G.; CAPELLA, P.; CONTE, L.S.; RUINI, F. Components of Royal Jelly. II. The lipid fraction, hydrocarbons and sterols. J. Apic. Res., v. 21, n. 3, p. $178-184,1982$.

[11] MOREno, P., SALVAdó, V. Determination of eight water- and fat-soluble vitamins in multi-vitamin pharmaceutical formulation by high-performance liquid chromatography. J. Chromatogr. A, n. 870, p. 207 215, 2000.

[12] PALMA, M.S. Composition of freshly harvested Brazilian Royal Jelly: identification of carbohydrates from the sugar fraction. J. Apic. Res., v. 31, n. 1, p. 42-44, 1992.

[13] TOWnsEnd, G.F., MORGAN, J.F., HAZLETT, B. Activity of 10-hydroxydecenoic acid from Royal Jelly against experimental leukaemia and ascitic tumours. Nature, v. 183, n. 4670, p. 1270-1271, 1959.

[14] WEAVER, N.; JOHNSTON, N.C.; BENJAMIN, R.; LAW, J.H. Novel fatty acids from the Royal Jelly of honeybees (Apis mellifera, L.). Lipids, v. 3, n. 6, p. 535-538, 1969.

\section{6 - ACKNOWLEDGMENTS}

The second author was supported by a grant from the "Conselho Nacional de Desenvolvimento Científico e Tecnológico” (CNPq). 